\title{
Strategies for a Phase 2 Road Map of Global Problem Solving Center 2030
}

\author{
Min-Soo Maeng ${ }^{1}$, Sung-Hoon Ahn' ${ }^{2}$, Ji-Hyun, Moon ${ }^{3}$, Seok Dockko ${ }^{1, \dagger}$ \\ ${ }^{1}$ Department of Civil and Environmental Engineering, Dankook University, Yong-in 31116, Republic of Korea \\ ${ }^{2}$ Department of Mechanical Engineering, Seoul National University, Seoul 08826, Republic of Korea \\ ${ }^{3}$ Graduate school of Environmental studies, Seoul National University, Seoul 08826, Republic of Korea
}

\section{0 글로벌문제해결거점 2단계 사업 추진전략 로드맵}

\author{
맹민수 ${ }^{1}$, 안성훈 $^{2}$, 문지현 ${ }^{3}$, 독고석 ${ }^{1, \dagger}$ \\ ${ }^{1}$ 토목환경공학과, 단국대학교, 용인시 31116 , 대한민국 \\ ${ }^{2}$ 기계공학부, 서울대학교, 서울시 08826 , 대한민국 \\ 3환경대학원, 서울대학교, 서울시 08826 , 대한민국
}

\begin{abstract}
1 단계 거점센터 사업이 종료됨에 따라 2 단계 거점센터의 필요성에 대한 공감대가 형성되어 최근 2 단계 글로벌문제해 결거점 2030 로드맵이 제시되었다. 2단계 거점센터의 비전은 지속 가능한 지구촌 공동체 실현을 위한 기술협력 플랫 폼 구축이다. 사업 방향성은 크게 3가지 핵심전략사업과 중점전략사업으로 구분된다. 핵심전략사업의 목표는 지속가 능/포용적/혁신적 과학기술 ODA 사업수행을 위한 글로벌 기술협력거점 및 융합기술 스마트 플랫폼 마련이며 핵심전 략사업 과제는 거점센터 중심의 글로벌 리빙랩을 통한 2단계 요소기술개발, 스마트 기술연계 체계구축 및 다자협력 사 업화 추진, ICT 기반 글로벌 핵심기술 운영 플랫폼 및 성과확산이 있다. 중점전략사업의 목표는 지속가능 기술구현을 통한 글로벌 거점지역 문제해결 및 국제협력이며 중점전략사업 과제는 기존 거점센터 2단계 전략기술의 ICT package 및 스마트 구축, 글로벌 리빙랩 중점기술에 대한 스마트 연계체계 개발, 거점센터의 기술성과 운영지원을 위한 글로벌 통합기술 비즈니스 지원 플랫폼 추진이다.
\end{abstract}

Due to the successful accomplishments of the first-stage base center project, a road-map for the second-stage, global base center 2030 project has recently been proposed. The vision of the base center is to build a technology centered, cooperation based platform for a sustainable global community. The global base center 2030 project is based on three core strategies as well as three key strategies. The main goal of the core strategy is to establish an interdisciplinary smart platform, as well as a global tech-coordination facility to implement sustainable, inclusive, and innovative science and technology based ODA projects. To achieve such goals, the global center will focus on developing a global living lab, interdisciplinary smart linkage systems, and a global operating platform. The main goals for the key strategies are to solve issues at the base centers while establishing an international relationship through sustainable technology. To achieve such goals, key projects are centered in establishing a ICT package, and a global living lab based on smart interconnected system. With this, a global inter-connected business platform will also be established to support technical and operational issues.

KEYWORDS: Living lab, International cooperation, Smart technology, ICT package, Sustainability

\footnotetext{
${ }^{\dagger}$ To whom correspondence should be addressed.

E-mail: seokdockko@gmail.com

Received: 26 April 2021, Revised: 15 June 2021,

Accepted: 15 June 2021
} 
서론

우리나라의 적정기술은 1970년대 정부 주도의 국가경제 산업발절을 이끌기 위한 핵심어로서 사용되었다(이도영, 2013). 그 이후 많은 이공계 전문가들 중심으로 2005년 크 리스천 과학기술포럼, 2006년 대안기술센터, 2008년 흙 부 대 생활기술 네트워크, 2009년 한밭대학교 적정기술연구소, 나눔과 기술, 국경없는 과학기술자회, 적정기술학회 등에서 적극적으로 활동하였다(Ahn, 2015). 2011년 이후부터 정부 및 지자체 그리고 기업들이 적정기술이라는 주제로 최신 과학기술과 결합하여 개발도상국에 지원하는 많은 프로그 램들을 추진하였으며 대표적으로 한국연구재단에서 운영 하고 있는 글로벌문제해결거점센터 사업이다(Baek et al., 2020). 적정과학기술거점센터(글로벌문제해결거점, 이하 거 점센터)는 지속가능발전목표(Sustainable Development Goals, $\mathrm{SDGs}$ )와 포용적 개발(Inclusive development)의 중요성을 강조하고 있으며 혁신적이고 포용적인 과학기술 $\mathrm{ODA}$ 를 지 원하고자 Figure 1과 같이 과거 박근혜 정부때 부터 창조경 제의 글로벌화를 위한 효과적인 방안으로 추진되고 있다 (Lee et al., 2014). 우리나라 과학기술 ODA는 적정기술의 지속가능한발전과 관련하여 경제적, 사회적, 환경적 지속가 능성과 과학기술혁신의 연계성을 가지고 개발도상국(캄보 디아, 베트남, 필리핀)에서의 과학기술 $\mathrm{ODA}$ 사업 가능성을 분석하였으며 이후에 '한국형 과학기술 ODA 로드맵' 정책 연구를 통해서 우리나라에서 과학기술을 이용한 ODA 사
업의 개념과 범위를 제시하였다(Lee et al., 2010; Lee et al., 2013). 과학기술 ODA 사업으로 과학기술정보통신부(이하 과기부)는 지속적으로 거점센터 사업으로 '개도국 과학기 술지원사업'을 추진해 오면서 적정과학기술을 통해 개도국 현지 문제 해결, 역량 강화, 삶의 질 제고 및 현지인의 자 생적 비즈니스 기반을 마련하는 것과 개도국 대학 및 연구 기관과의 협력을 통해 현지 적정과학기술 역량을 강화하는 것에 중점적으로 사업을 추진하고 있다. 현재 거점센터는 개도국의 주요 거점에 센터를 구축하고 국내 과학자 파견, 현지조사, 연구개발, 교육, 응용화 등을 4 년간 약 20 억 원의 사업비로 진행하고 있다. 주요 사업내용은 현지 지역 공동 체/지방 정부, 국내 협력본부 및 현지 대학/연구기관과 긴밀 하게 협력하면서 현지 수요 조사, 적정과학기술 현지화, 시 범 사업 추관, 현지 인력 교육 훈련, 적정기술프로그램개발 상용화, 비즈니스 네트워크를 구축하는 것이었다. 현지센터 운영을 위해 개도국 정부.기관에서 거점센터 공간을 제공 (대학 또는 연구기관 활용)하고 국내 주관기관에서 파견한 센터장 외에도, 연구지원 및 사후관리를 위해 센터마다 월 드프렌즈 과학기술지원단(WFK- TPC)이 2 3인 내외로 파 견되어 현지에 상주하여 수행하였다. 2013년 캄보디아를 시 작으로 현재까지 라오스, 네팔, 탄자니아, 에디오피아, 인도 네시아, 미얀마 등 8 개국에 지역의 수요에 따른 개별 주제 를 지닌 8 개의 거점을 구축하여 개도국 지역사회개발에 필 요한 포용적이고 혁신적인 적정기술의 연구개발과 교육 및 사업화의 성과를 도출하여 한국형 과학기술 $\mathrm{ODA}$ 의 주요

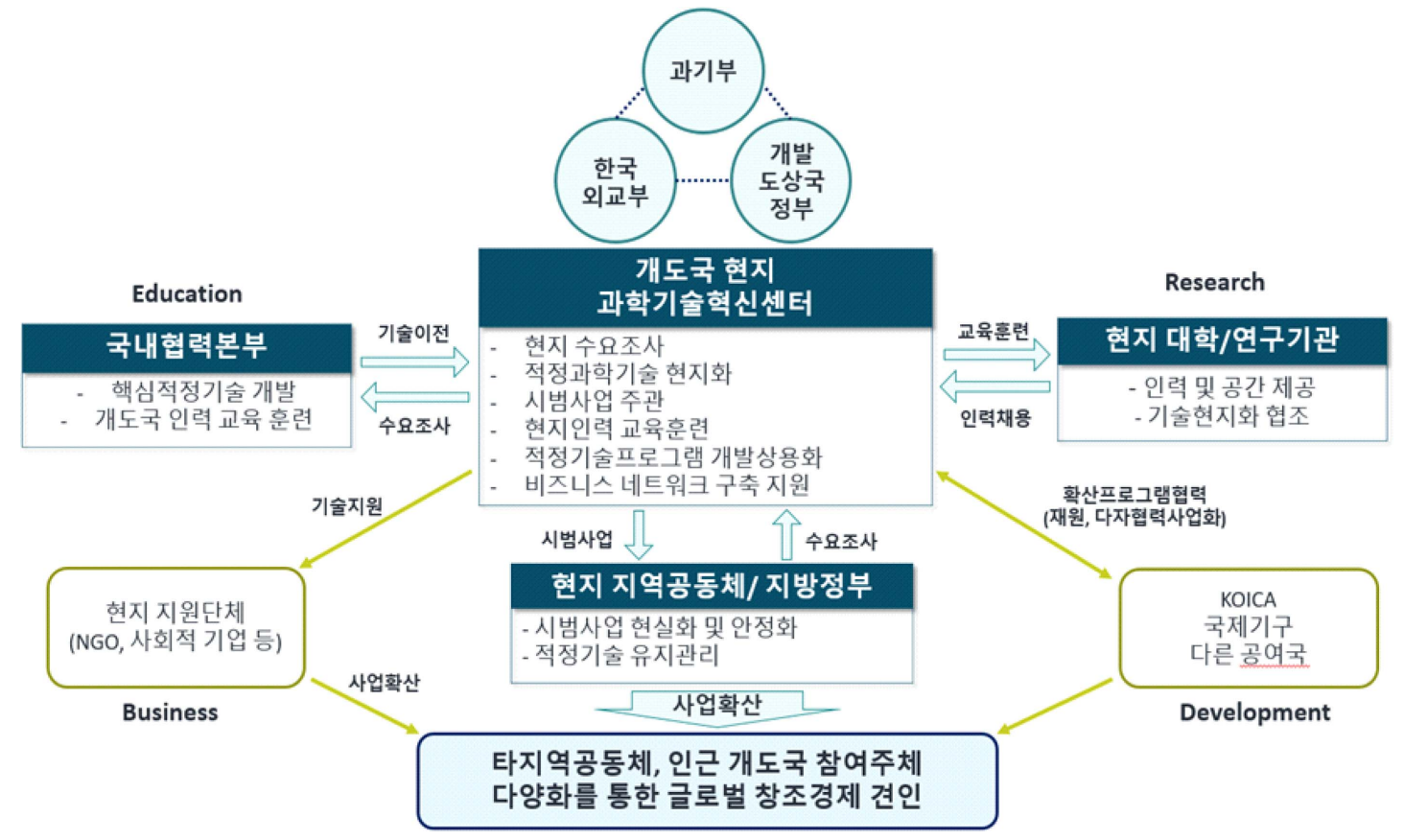

Figure 1. 거점센터 사업추진 체계 
추진모형으로 자리매김하였다. 과기부는 8 호 거점센터를 마지막 사업으로 결정하면서 향후 추가 거점센터에 대한 지원이 어렵게 되었다. 하지만, 그간 거점센터를 통해서 도 출한 과학기술 $\mathrm{ODA}$ 의 많은 성과와 지속적인 지원 필요성 에 대한 공감대가 전문가 집단을 통해서 형성되어 최근 2 단계 글로벌문베해결거점 2030 로드맵을 출간함으로써 2 단계 거점센터의 비젼을 제시하였다. 본 연구에서는 2 단계 거점센터의 구체적인 사업전략과 방향에 대해서 3가지 핵 심전략사업과 중점전략사업으로 구분하여 구체적인 사업 에 대한 방향성을 제시고자 한다.

\section{2단계 거점센터 추진 방법}

\section{1 단계 거점센터의 성과와 과제}

Figure 2와 같이 2020년 현재 8개 국가에서 분야별 과학 기술 특징을 지닌 거점센터가 설립되어 적정기술 연구개발 및 교육과 사업화의 성과를 도출하였다. 첫 번째 캄보디아 글로벌 물 거점센터는 식수 분야와 위생 분야에서 식수 장 치 개발 사업 및 정화조 개발을 통한 위생 사업을 시행하 였다. 지역사회보급형 대용량 정수시설(SBBR)을 개발하여 마을에 식수 시설을 제공하였으며, 비즈니스 모델을 적용 하였다. 위생 사업으로는 기존 사용 중인 정화조의 문제점 을 개선하고, 3 단 밀폐형 정화조와 자연친화적 처리방식을 도입한 화장실을 개발하여 유지관리 및 경제성을 제고하였 다. 두 번째 라오스 에너지 및 농식품 거점센터는 전통음식 인 민물김(카이펜)의 위생상태와 품질을 적정기술을 활용 하여 개선하고, 생산시설 구축과 상품화를 통해 라오스 농 촌지역의 여성 일자리 제공과 지속적인 소득 증대를 도모 하였다. 또한 소규모 송배전망(마이크로 그리드)용 태양광 및 피코수력 연계 발전용 하이브리드 발전시설로 농촌전력 화 사업을 통해 마을주민의 역량강화 및 고용기회를 제공 하였다. 세 번째 네팔 거점센터는 히말라야 천연섬유 알로 를 이용한 마을 기업을 육성하여 알로혼방사 신산업을 성 장시켰다. 적정기술 이중창업 프로세스를 통하여 지역사회 개발 및 지속가능 생태계를 구성하고 현지 대학에 적정기 술 창업과정을 내재화하는 것을 주요 전략으로 하였다. 히 말라야 천연자원을 가공하는 마을기업과 이를 지원하는 기 술기업을 육성하여 기술생태계를 조성하였다. 네 번째 탄 자니아 에너지-산업연계거점센터는 신재생 에너지기반 농 촌 전력화와 지역사회개발, 백신 냉장고를 통한 보건의료 사업을 수행하고, 테크샵과 스마트 팩토리를 구축하여 청 년창업팀을 보육하고 기술사업화를 추진하였으며 국제컨 퍼런스와 창업경진대회를 진행하여 국제협력과 역량강화 의 플랫폼을 구축하고 성과확산을 도모하였다. 태양광 발

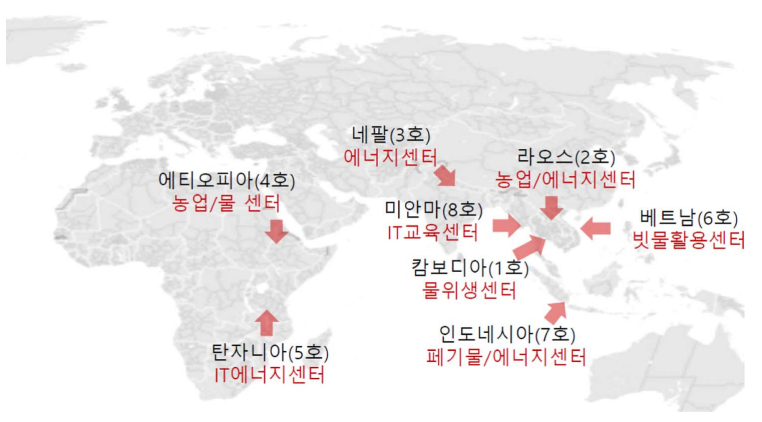

Figure 2. 글로벌 거점센터 현황

전과 백신냉장고에 스마트 기술시스템을 도입하여 아프리 카 4차산업에 적합한 적정스마트기술 모델을 개발하였다. 다섯 번째 에티오피아 물/농업 거점센터는 지하수 불소제 거를 위한 고흡착 골탄을 개발하여 마을형 정수시스템을 설치하여 안정한 식수를 공급하고 지속가능한 운영을 위해 비즈니스 모델을 도입하였다. 농업분야에서 고부가가치 느 타리버섯 재배 및 우수버섯종균확보를 위한 오존클린밴치 장치를 개발하여 마을에 버섯 재배시설을 구축하며 농업 비즈니스 모델을 구현하였다. 여섯 번째 베트남 수자원/위 생 거점센터는 학교와 관공서 등 공동체 단위에서 빗물을 활용하여 안전한 식수공급이 가능하도록 하였으며, 초절수 형 화장실 시스템 및 자원순환형 화장실을 보급하였다. 지 속가능성 측면에서 IT를 이용하여 유지관리시스템과 경제 적 확산 모델을 구축하였다. 일곱 번째 인도네시아 저탄소 통합폐기물관리 거점센터는 4R (Reduce, Reuse, Recycle, Recovery) 원칙에 입각하여 폐기물 및 폐자원 관리 시스템 의 주요 구성요소들을 개선하도록 하였다. 현지 니즈를 조 사하고 그에 맞는 문제해결형 적정기술을 매치하며 적정과 학기술 현지화를 이루었다. 역량강화 프로그램을 기획하여 시행하고 센터의 지속가능성과 자립화 방안을 모색하고 있 다. 마지막인 여덟 번째 미얀마 IoT/AMI 기술혁신 거점센 터는 국립 UCSY 대학에 SDN/cloud 기반의 국제간 네트워 크 기반을 구축하고 미얀마 국가 연구교육망으로 확산하는 기술혁신센터를 구축하였다. 이를 통해 네트워크 기반의 원격교육, IoT/ AMI 기술개발 프로젝트를 시행 중이며 미 얀마 도시 및 산업 인프라에 적용하여 혁신 성장 동력이 되 는 기술개발 및 인력 양성을 도모하고 있다.

거점센터 사업은 기존 과학기술의 단순기술지원을 넘어 수혜자 중심의 비즈니스 창출을 통해 적정기술의 상용화로 연결하는 ODA 패러다임을 수립함으로써 원조효과성 제고 라는 글로벌 아젠다에 부합하는 혁신적이고 효과적인 $\mathrm{ODA}$ 사업이었다. 또한 그림 3과 같이 현지의 기술적 수요 (Needs)를 바탕으로 현지 협력기관에 인프라를 구축하여 교 육(Education), 연구(Research), 개발(Development), 산업화 


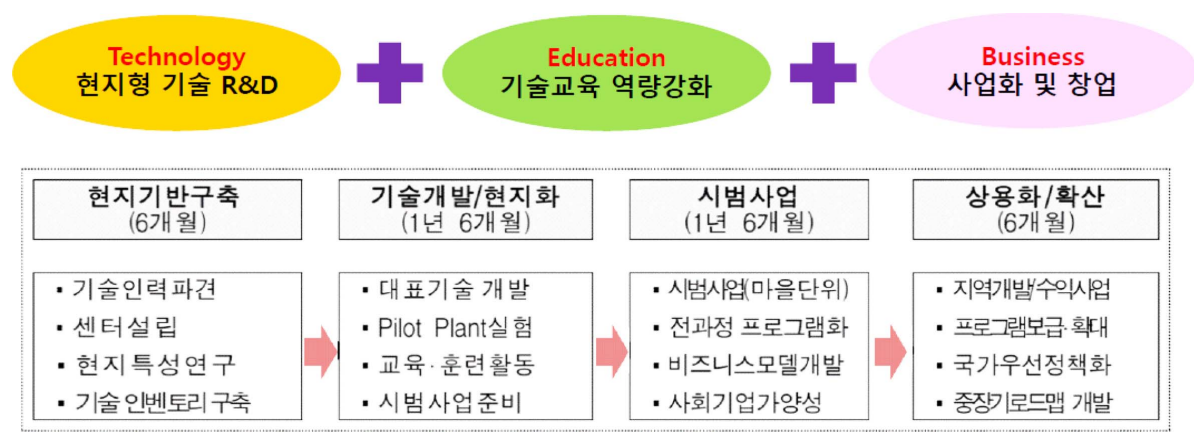

Figure 3. 거점센터의 사업추진내용

(Business)를 동시에 수행함으로써 개도국에 한국 경제성장 의 노하우를 전달하고 우호적인 관계를 형성하는 효과적인 역할을 수행하기도 하였다.

거점센터는 현지의 기술적 수요에 기반하여 현지에 적합 한 적정기술을 보급하였으며, 현지 대학 및 정부기관과 협 력하며 기술 교육과 연구, 개발, 산업화를 모두 충족시켰다. 이를 통해 한국의 압축성장 노하우를 전달하며 현지 대학 인프라에 기반한 기술연구 개발을 지속해왔다. 한국의 기 술과 경험을 일방적으로 전수하는 접근방식이 아니라 현지 에 직접 전문 기술자들이 상주하면서, 현지 수요에 맞는 기 술을 개발하고 이를 적용하고 보급하였다는 점에서 한국형 $\mathrm{ODA}$ 의 문제점과 한계를 보완한 새로운 과학기술 ODA 모 델이었다고 할 수 있다. 특히 한국의 과학기술혁신 발전 경 험을 개도국에 전수하여 경제성장을 독려했다는 측면에서 국제사회에서 한국의 리더십을 제고하고 과학기술 외교력 을 증대하여 과학한류 조성에 기여한 우수한 사업으로 평 가된다. 그러나, 연구개발(R\&D), 교육(E), 사업화(B)의 방 향과 내용은 좋았으나 이에 비해 사업기간(4년 +2 년)이 매 우 짧아 사업효과를 얻기에는 어렵다는 단점을 지녔으며,
현재 거점센터 과제가 일몰 사업화되어 8 개의 센터를 마지 막으로 사업이 중단된 상황이다. 또한 4개년 본 사업 후 2 개년의 추가사업비가(연간 1 억 2억 내외)가 적어서 성과유 지 및 발전이 어려웠을 뿐 아니라, 일몰사업화 이후 2개년 의 추가지원 조차도 받지 못하는 거점센터도 있어 지속가 능성의 문제가 제기되고 있다. 국내 ODA지원 규모가 지속 적으로 증가함에 따라 국제협력 기회가 확대되고 있으며, 국내 청년·실버 봉사단 파견 희망자 또한 증가하고 있다. 이 러한 상황에서 현지 필요 기술 수요의 정확한 판단을 바탕 으로 지난 6 년 간 1 단계 거점센터가 구축해 온 현지의 인 적 네트워크와 역량을 활용하는 2 단계 거점센터 사업의 진 행이 필요하다.

\section{2. 거점센터의 단계별 비전과 목표}

2013년 거점센터 사업추진 시 계획된 추진일정은 4년의 단기적인 과정으로 끝내고 독립시키는 방식이 아니라, 4단 계에 걸쳐 10 여 년간 지속적인 지원과 협력이 가능한 체제 로 구축하는 것을 지향하고 시작하였다. 비록 BORDA나 Practical Action과 같은 국제 적정기술기관이 40 50년 간

\section{Strengths}

- 현지의기술적수요에기반
- 교육E+연구R+개발 $\mathrm{D}+$ 산업화R충족
- 한국의압축성장 노하우전달
- 현지대학인프라에기반한기술연구개
Opportunities
Oppor
- 국내 ODA지원규모의지속적증가에
따른 국제협력기회확대
- 6년 간의현지인적네트워크활용
- 현지필요 기술의수요정확한판단
- 국내 청년/실버파견 희망자증가

\section{Weaknesses}

- 개발기술표준화

- 현지인기술습득능력에어려움

- 공공분야(물, 폐기물, 에너지)와

민간 분야(IT, bio,제조업)의 성과목표상이

- 파견단원의중장기체류시처우문졔

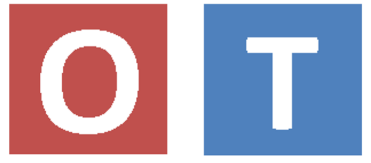

\section{Threats}

- COVID19로 인한 해외사업곤란

- 산업화를 위한 현지시장이졔한적

- 현지/국내 행정지원체계에 한계

- RE\&BD를 4년만에 수행하는것에

대한업무과중

Figure 4. 거점센터 SWOT 분석 
진행한 것에 비해 짧은 것이었으나, 거점센터는 시작단계 에서부터 단발성 프로젝트가 아닌 사업의 지속가능성을 고 려하여 설계되었다.

Table 1. 거점센터 추진일정 (기존)

\begin{tabular}{|c|c|c|}
\hline 시 기 & 목 표 & 주요 추진 사업 \\
\hline $\begin{array}{c}1 \text { 단계 } \\
\text { (2013 } \\
\text { 2015) }\end{array}$ & $\begin{array}{l}\text { 적정 과학기술을 } \\
\text { 통한 ODA 추진 } \\
\text { 방향 정립 }\end{array}$ & $\begin{array}{l}\text { - 적정기술을 통한 ODA 추진 국가 전략 } \\
\text { 마련 } \\
\text { - 지역별 (아시아, 아프리카) 거점센터의 } \\
\text { 설치(개발 및 시범사업) } \\
\text { - 국내 적정기술 연구개발 센터 설치 }\end{array}$ \\
\hline $\begin{array}{c}2 \text { 단계 } \\
\text { (2015 } \\
2017)\end{array}$ & $\begin{array}{l}\text { 적정 과학기술 } \\
\text { 협력을 위한 기반 } \\
\text { 구축 }\end{array}$ & $\begin{array}{l}\text { - 적정 과학기술 모델 프로그램의 개발 } \\
\text { - 개도국별 적정기술 거점센터 확대 } \\
\text { - 모델 프로그램 국가차원의 확대 }\end{array}$ \\
\hline $\begin{array}{l}3 \text { 단계 } \\
(2017 \\
2019)\end{array}$ & $\begin{array}{l}\text { 국제적인 적정기 } \\
\text { 술 모델 프로그램 } \\
\text { 의 개발 }\end{array}$ & $\begin{array}{l}\text { - 적정 과학기술 네트워크의 구축 } \\
\text { - 적정기술 주요 분야별 국제 협력 프로 } \\
\text { 그램 개발 }\end{array}$ \\
\hline $\begin{array}{l}4 \text { 단계 } \\
(2019 \text { } \\
2022)\end{array}$ & $\begin{array}{l}\text { 성과확산 및 적정 } \\
\text { 과학기술의 선도 } \\
\text { 적 지위확보 }\end{array}$ & $\begin{array}{l}\text { - 국제 적정기술 협력센터(국제기구) 설치 } \\
\text { - 선진국들의 적정 과학기술 기구들과 협력 } \\
\text { 체계 구축 } \\
\text { - 적정 과학기술 국제 협력 프로그램의 확산 }\end{array}$ \\
\hline
\end{tabular}

적정기술 거점센터는 위와 같이 4단계 일정으로 추진하 도록 기획되었는데, 첫 번째 단계는 방향정립단계 및 시범 사업, 두 번째 단계는 모델 프로그램의 개발 및 기반구축, 세 번째 단계는 그간의 성과를 바탕으로 한 국제협력프로 그램 개발, 마지막 4단계는 성과확산 선도적 지위확보단계 였다. 2단계까지 5년 동안 적정기술 거점센터가 개발도상 국내 기반을 확보하는 것을 목표로 하였고, 다음 5 년 동안 적정기술 분야의 선도적 지위를 확보하는 것으로 설정하였 다(Lim, 2015). 그러나, 2013년부터 2020년까지 실시된 1호 에서 5호 센터까지의 실제 사업은 '4년 본 사업' 후 축소된 예산으로 '2년 유지관리'이후 종료됨으로써 4단계까지의 목표달성을 위해 2 단계를 실행하기 보다는 1 단계 사업에서 성급히 마무리하였을 뿐 당초 계획되었던 2단계 사업을 실 행하였다고 보기 어렵다. 2030년까지 새롭게 진행될 로드 맵에 따라 기존의 거점센터 사업을 1 단계로, 향후 10 년간의 사업을 2 단계로 기획한다면, 기존의 2 단계 목표였던 '적정 과학기술협력을 위한 기반구축'을 시작으로 국제협력사업 에 적용할 적정기술 모델개발의 완성도를 높여 가면서 '적 정기술 국제협력 플랫폼'의 역할을 수행해야 한다. 지속가 능한 지구촌을 위한 기술협력 플랫폼을 비전으로, 적정기 술의 보급 및 확산지원을 목표로 하는 것인데, 이를 위해 다 양한 형태로 존재하는 기존의 적정기술의 경험을 공유하며 협업하여 네트워크를 구축함으로써 지식과 경험을 공유하 고, 사업 협력체계를 강화해야 한다. 이를 위해 국제 적정 기술 협력센터(국제기구) 설치, 기존 개도국 과학기술 협력
사업 추진기관들의 거버넌스 구축 혹은 통합, 선진국들의 적정과학기술 기구들과 협력체계 구축, 적정과학기술 국제 협력 프로그램의 확산 등을 실행해야 하며, 이는 적정기술 을 통한 개발협력의 선도적 지위를 확보하고 지속가능개발 목표(SDGs)의 달성에 기여하도록 맞추어져야 한다. 현지거 점센터의 지속가능발전지원방안 연구보고서에 따르면 적 정기술 거점센터가 거점으로서의 역할을 하기 위해서는 거 점 대학 내에 기술협력을 위한 협력체계를 구축하고, 활동 의 물리적 근거가 되는 공간이 필요하다. 또한 거점센터의 활동을 담당할 전문인력들과 적정기술활동의 기반이 되는 핵심기술이 있어야 하고, 활동의 재정적 지속가능성이 유 지되어야 한다(Choi, 2017). 거점센터가 기술협력의 플랫폼 이 되기 위해서는 기술의 수요자와 공급자, 재정지원조직 들, 현지의 정부와 개발협력 단체와 국제기구 등과 네트워 크를 잘 구축해야 한다. 현지 네트워크 구축을 위한 정기적 인 프로그램도 필요하다. 구체적으로 기술과 경험을 교류 하기 위한 정기적인 세미나나 워크숍 등을 시행할 수 있을 것이다. 향후 거점센터가 담당해야할 역할 중 하나는 기술 현지화를 위한 테스트베드 운영이다. 개도국 진출을 원하 는 중소기업들이 보유하고 있는 기술이 현지에서 보급되려 면 현지의 수요와 여건에 맞게 현지화 되는 과정이 필요하 다. 국내에서는 잘 적용되고 있는 기술이라 하더라도 현지 에 적용되려면 기후와 문화, 사회경제적 여건 등에 따라서 적정화되어야 하기 때문이다. 또한 현지에 필요한 문제를 해결할 수 있는 전문인력이나 기술인력을 육성하는 것이 필요하다. 적정기술 교육 훈련 및 인력양성 적정기술과 관 련한 교육훈련은 대학 내에 관련 과목을 개설하여 강의를 진행하거나, 일정 기간의 교육훈련프로그램을 자체적으로 실시하는 방법, $\mathrm{KOICA}$ 등의 초청 연수 등을 활용하는 방 안 등이 있을 것이다. 국내 중소기업, 개발협력 $\mathrm{NGO}$ 등에

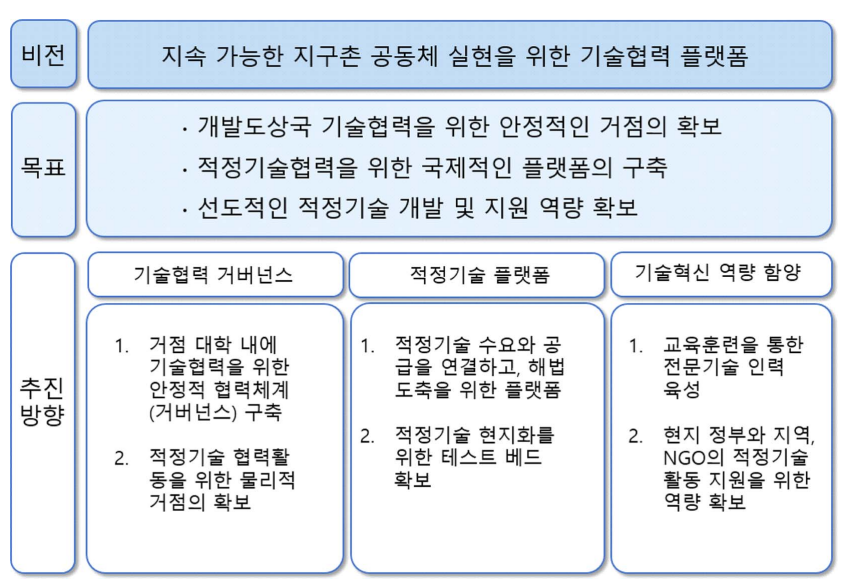

Figure 5. 거점센터의 비전과 목표 
서 적정기술 보급사업을 다양한 방식으로 추진하고 있지만, 기술적 전문성이 부족하여 사업에 어려움을 겪는 경우가 많다. 적정기술거점센터는 개발도상국과의 기술협력사업 뿐만 아니라 다양한 협력사업 과정에서 필요한 기술적 지 원을 담당할 수 있어야 한다. 또 거점센터에서 모든 기술지 원 수요를 담당할 수 없을 것이기 때문에 다른 전문기관들 과 기술교류 등의 협력체계를 갖추어야 한다.

\section{2단계 거점센터의 방향성}

최근 국제사회는 공여국이 다자기구를 통해 지원하되 특 정국가·지역·분야·주제로 지원대상을 지정(earmarked)하는 다자성 양자(multi-bi) 지원형태가 확대되고 있다. 다자기구 를 통한 지원이지만 양자원조 성격이 강하여 다자성 양자 (multi-bi) 원조는 기본적으로 DAC 통계상 양자원조로 분류 되고 있지만, 비핵심(non-core) 사업으로 유엔기구에 대한 지정기여와 MDBs에 대한 신탁기금 등이 대표적인 사례이 다. 다자기구 지원 사업은 그 형태에 따라 출연(분담금 포 함), 출자, 양허성 차관으로 구분하며, 지원 성격에 따라 분 담금 또는 출자금과 같은 비지정기여(core)와 신탁기금과 같은 지정기여(non-core) 또는 다자적 양자(multi-bi)로 나누 기도 한다. 출연금은 넓은 의미로 해석할 때 국제기구에 대 한 분담금을 의미하며 $\mathrm{UN}$ 기구, $\mathrm{ADB}, \mathrm{IDB}$ 특별기금 등에 납입하는 출연금 또는 분담금이 이에 해당된다. 출자금은 국제기구 가입, 지분확대 등을 목적으로 국제기구에 납입 하는 것으로 국제기구 신규가입비, IDA·ADF 등 정기 재원 보충 참여 등을 위한 지원금이 해당된다. 2 단계 거점센터는 과학기술·ICT 관련하여 국제기구와의 협력사업 발굴 및 양 자사업과의 연계를 강화할 필요가 있다. 과학기술 ICT 분 야의 중장기 다자간 협력 이슈를 도출하고 양자간 사업과 연계를 고려하면서 대응전략 및 아젠다의 선제적 제시가 필요하다. 글로벌 도전과제에 대한 국제협력 중점 추진과 제와 연계한 국제기구 참여 전략을 수립하여 UN, ITU (국 제전기통신연합), $\mathrm{OECD}, \mathrm{APEC}$ 등 관련 국제기구 아젠다 를 설정하고 공동사업 개발 시행에 적극 참여하여 국가적 차원의 중점협력 대상기구 및 지원분야 선정을 통하여 다 자협력 효과성을 제고할 필요가 있다. 이러한 국제기구의 다자성 양자 사업의 추세 및 국내 ODA 유무상 연계 확대 와 현 정부의 신남방 정책은 2 단계 거점센터의 향후 사업 추진의 기회이자 방향성을 제시하고 있다.

현 정부가 추진하는 신남방 정책은 3P (People, Peace, Prosperity)를 기반으로 하여 개발격차완화 및 지속가능개발 등 한국의 차별성 있는 $\mathrm{ODA}$ 를 추진하는 것으로 5 대 중점 프로그램은 수원국의 수요를 바탕으로 디지털 파트너십, 고등교육, 농촌개발 및 지원, 스마트 도시 개발, 포용적 교
통 등인데, 이것은 포용적 개발을 목표로 하는 적정과학기 술거점센터 사업을 통해 효과적으로 실현될 수 있다.

Table 2. 신남방 ODA 5대 중점 프로그램

\begin{tabular}{|c|c|c|c|}
\hline \multicolumn{2}{|r|}{ 5대 중점 프로그램 } & \multirow{2}{*}{\multicolumn{2}{|c|}{ 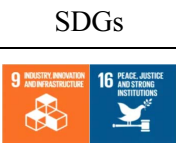 }} \\
\hline & $\begin{array}{l}\text { 포용적 개발을 위한 } \\
\text { 디지털 파트너십 }\end{array}$ & & \\
\hline & $\begin{array}{c}\text { 더 나은 미래를 위한 } \\
\text { 고등교육 }\end{array}$ & 4 & 9 \\
\hline & $\begin{array}{c}\text { 포용적이고 지속가능한 } \\
\text { 농촌개발 및 지뢰제거 } \\
\text { (한-메콩 미래 평화공동체 사업) }\end{array}$ & 2 III & 8 \\
\hline & $\begin{array}{c}\text { 자연과 사람이 함께하는 } \\
\text { 스마트 도시개발 }\end{array}$ & A 11 : & 8 \\
\hline & $\begin{array}{c}\text { 균형성장을 견인하는 } \\
\text { 포용적 교통 }\end{array}$ & 9 & 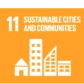 \\
\hline
\end{tabular}

2단계 거점센터의 방향성은 기후변화, 신남방 정책, 스마 트 연계체제를 반영하여 기존 8 개 거점센터의 1 단계 성과 위에 핵심 분야인 물순환, 저에너지, 스마트 농업, ICT 등 2단계 요소기술개발과 이러한 기술들을 스마트 Packaging 으로 연계함으로서 글로벌 다자간 협력사업 등을 통한 글 로벌 기술공유 플랫폼으로 성장시키고자 한다. 그리고 현 지형 기술 수요를 기반으로 한 창업보육 비즈니스 센터로 특화하고 필요한 기술을 기초, 응용, 고도 기술로 분류하여 이에 따라 적합한 전문 인력을 지원하도록 한다. 특히 현지 대학 등 기존에 구축된 교육 인프라와 연구개발, 산업화를 연계하여 안정적인 기술 기반 창업보육 비즈니스 환경을 구축한다. 글로벌 리빙랩을 운영하여 각 지역내 필요한 기 술을 국내 지역내 기술과 연계시킨 STI 센터의 형태로 1 단 계 10 년, 2 단계 10 년의 장기적 지원센터로 운영하도록 한 다. 이를 위해 기존 적정기술센터의 인적 네트워크를 활용 할 예정이며 국내 도시과 현지 지역을 자매결연하여 스마 트 빌리지 조성, 봉사단 파견 희망 인력의 증가라는 기회에 발맞추어 단기(1-2년 기술 봉사), 중장기(3-10년) 전문 기술 봉사단을 파견한다. 중장기 STI 지원 시 기술표준화 방안을 마련할 필요가 있다. 뿐만 아니라 효율적인 행정 지원을 위 해 STI 지원 시 기술전수에 적합한 현지 인력 선발과 배치 가 필요하다. 또한 공공분야와 민간분야의 성과목표를 각 각 설정하여 각 목표에 따른 효율적인 운영이 가능하도록 하며 중장기 STI 지원 시 전체관리 행정지원 시스템을 마 련해야 한다. 최근 세계적 쟁점이 되는 COVID19와 기후변 화라는 지구적 위협에 대응하는 방안을 체계적으로 마련하 여 국내 디지털 그린뉴딜 마을 개선사업을 현지 글로벌 리 
빙랩에 적정기술을 통해 중장기적 관점으로 운영한다. COVID19 백신 접종 이후에도 비대면 R\&BD 방안을 추진 하여 각 센터별 적정기술을 활용하여 기후변화대응 개선사 업으로 연계를 추진하며 디지털 그린 뉴딜 정책과 부합하 도록 한다.

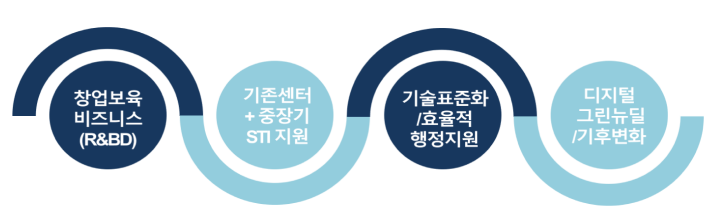

Figure 6. 2단계 글로벌 리빙랩 기반 STI 지원센터

2단계 거점센터는 COVID19, 비대면사회, 디지털/그린뉴 딜, 기후변화, SDGs 등 빠르게 변화하는 글로벌 이슈에 선 제적으로 대응하는 신사업분야 기술 R\&D 컨텐츠를 개발 해 나갈 수 있다.

위와 같은 신사업분야를 2 단계 거점센터에 적용한다면 8 개의 각 거점센터의 주제를 아래와 같이 확장하여 진행할 수 있다.

Table 4. 2단계 거점센터 사업구성안(캄보디아)

\begin{tabular}{|c|c|c|}
\hline \multicolumn{3}{|c|}{ 2단계 거점센터 사업구상(안), 캄보디아(예시) } \\
\hline 사업 & \multicolumn{2}{|c|}{ 스마트 저영향개발(LID) 마을조성사업 } \\
\hline \multirow{2}{*}{ 대상지역 } & \multicolumn{2}{|c|}{ 캄보디아 캄퐁스푸지역 - 프놈펜 인접지역으로 } \\
개발가능성이 큼
\end{tabular}

Table 3. 2단계 거점센터의 방향

\begin{tabular}{|c|c|}
\hline 신사업 분야 & 내용 \\
\hline $\begin{array}{c}\text { 디지털/ } \\
\text { 그린뉴딜 }\end{array}$ & $\begin{array}{c}\text { 비대면 기반IT+적정기술, } \mathrm{AI} \text { 무인화, } \\
\text { 디지털행정, 원격교육 }\end{array}$ \\
\hline 기후변화/저에너지 & $\begin{array}{c}\text { 홍수가뭄, 사막화, 저탄소배출, } \\
\text { 배출권거래, 태양광, 대기오염 }\end{array}$ \\
\hline $\begin{array}{c}\text { 보건/생명/ } \\
\text { 식량자원 }\end{array}$ & $\begin{array}{c}\text { COVID 보건, 의료, 방역, 농업, } \\
\text { DNA생명공학, Bioresource Tech }\end{array}$ \\
\hline 물위생 환경 & $\begin{array}{c}\text { 수질오염, 식수, LID, 친수환경, } \\
\text { 중금속 오염, 위생설비 }\end{array}$ \\
\hline 재난안전 & $\begin{array}{c}\text { 지진예측, 방재기술, 자산관리기술, } \\
\text { 도시안전관리기술 }\end{array}$ \\
\hline
\end{tabular}

Table 5. 2단계 거점센터 사업구성안

\begin{tabular}{|c|c|c|}
\hline 국가 & 주제 & 사업명 \\
\hline 캄보디아 & 물위생 & $\begin{array}{c}\text { 스마트 저영향개발(LID) 주거환경 } \\
\text { 조성사업 }\end{array}$ \\
\hline 베트남 & 빗물 활용 & $\begin{array}{c}\text { 기후변화대응 스마트 물순환 } \\
\text { 주거환경조성사업 }\end{array}$ \\
\hline 라오스 & 농업/에너지 & iT접목 스마트농업 농촌보급사업 \\
\hline 에티오피아 & 물/농업 & $\begin{array}{c}\text { iT연계 스마트 농촌자립 } \\
\text { 마을 구축사업 }\end{array}$ \\
\hline 네팔 & 에너지 & $\begin{array}{c}\text { 기후변화대응 iT기반 친환경 } \\
\text { 에너지 보급사업 }\end{array}$ \\
\hline 인도네시아 & 폐기물/에너지 & 친환경 저에너지시설 보급사업 \\
\hline 탄자니아 & iT에너지 & AI기반 생산자동화시설 보급사업 \\
\hline 미얀마 & iT교육 & iT교육 컨텐츠개발 및 보급사업 \\
\hline
\end{tabular}

\section{연구결과}

\section{2단계 거점센터 핵심전략과제}

\section{1 거점센터 중심의 글로벌 리빙랩 통한 2단계 요소기술개발}

기존 8 개 거점센터의 주요 핵심 분야인 물순환, 저에너지, 스마트 농업, ICT 등의 주요성과를 통한 2단계 요소기술개 발로 국제 표준화 기준마련하고 지역 간 문제 해결을 효과 적인 해결하고 센터의 지역사회 정착 유도를 위한 글로벌 리빙랩 운영 및 모니터링을 위함이다. 1단계 거점센터의 기 술혁신성과를 기반으로 2 단계에서는 유사 주제별로 물, 농 업, 에너지 및 ICT 등 4가지로 나누어 전략적 방안을 제시 하고자 한다. 2 단계에서는 기존 거점센터에 개발된 기초기 술 위에 기후변화를 고려한 물순환, 스마트 생명농업, 친환 경 저에너지 및 $\mathrm{AI}$ 기반 자동화/ICT교육 등의 분야별 주요 핵심 기술들을 현지 지역 주민 참여형 방법의 리빙랩을 구 축하여, 마을개선에 필요한 요소기술을 한국 마을-현지 마 을이 거점센터를 중심으로 공동으로 개발하여 마을 개선에 적용한다. 개발된 핵심 요소기술들은 기술 표준화하여 개 발도상국의 분야별 주요 핵심기술이 센터에서 개발될 요소 기술로써 사용할 수 있도록 전략적으로 접근하고자 한다. 글로벌 리빙랩은 기술제공자와 사용자가 지속적인 논의와 모니터링 진행하는 혁신 공간이다.

실제로 기술을 사용하는 현지주민들의 피드백을 수집함 으로써 센터들의 핵심요소기술이 현지에 적합하게 반영할 수 있도록 향상시킬 수 있다. 8 개 센터들은 리빙랩 모니터 링을 통해서 분야별 기술의 적절성, 효과성, 효율성, 지속가 능성의 피드백을 데이터 베이스화 시킴으로써 주요 핵심 기술로서 자리매김 할 수 있도록 추진한다. 


\section{거점센터 Road Map 지역별 사업주제(안)}

\section{신남방+스마트시티+대학교육+iCT+보건/위생/의료기반+기후변화+SDGs}

- [1.캄보디아: 물위생] 스마트 저영향개발(LID)주거환경 조성사업

- [6. 베트남: 빗물활용] 기후변화 대응 스마트 물순환 주거환경 조성사업

- [2. 라오스: 농업/에너지] iT접목 스마트 농업 농촌보급사업

- [4. 에티오피아: 물/농업] iT연계 스마트 농촌 자립마을 구축사업

- [3. 네팔: 에너지] 기후변화 대응 iT기반 친환경 에너지 보급사업

- [7. 인도네시아: 폐기물/에너지] 친환경 저에너지 시설보급사업

- [5. 탄자니아: iT에너지] AI기반 생산 자동화시설 보급사업

- [8. 미안마: iT교육] iT 교육 컨텐츠 개발 및 보급사업
스마트마을개선

물순환환경

기후변화대응

스마트농업

ICT기술

생명공학

ICT기반

칙화경에너지

기후변화대응

AI기반

자동화

iT대학교육

Figure 7. 거점센터별 2단계 사업 주제

\section{2. 스마트 기술연계 체계구축 및 다자협력 사업화 추진}

1 단계 기술성과와 2단계 핵심 요소기술 연계의 스마트 기 술체계 구축을 위한 ICT package 사업으로 8개 센터의 거 점국 및 주변국 시장 연계 지원을 통한 다자간 핵심전략기 술 산업 육성하고자 한다. 1단계 센터별 분야 핵심 성과들 을 2단계 센터별 핵심요소기술에 ICT 기술을 융합시켜 스 마트 기술체계를 구축하고자 한다. 최근 개발도상국의 ICT 기술력이 향상되는 점을 고려하여 국내 ICT 우위 기술들을 분야별 핵심기술에 적용할 수 있도록 현지화 시키고자 한 다. ICT 기술의 지속가능한 방법을 개발하고 지역사회에 스 마트한 기술체계를 구축함으로써 글로벌한 적정기술 모델 을 개발하고자 한다. 특히 인공지능과 같은 스마트 기술을 핵심 요소기술에 적절하게 현지에 적용시키기 위해서는 기 술의 지속적인 모니터링을 통한 빅테이타 구축 및 분석으 로 현지 지속가능한 ICT package 사업을 구축하고자 한다. 스마트 기술체계 구축은 센터의 거점국 뿐만 아니라 주변 국까지 운영할 수 있는 역량을 갖고 있다. 센터에서는 분야 별 핵심전략기술 및 성과공유 온라인 플랫폼을 운영함으로 써 기술혁신을 위한 글로벌 스마트 사업을 추진할 수 있다. 센터는 현지 정부사업 및 국제 협력사업에 참여하여 ICT 기술을 융합한 핵심기술로 다자협력 프로젝트는 추진할 수 있다. 또한, 지역 주민에게 온라인 리빙랩을 운영할 수 있 는 글로벌 플랫폼을 제공함으로써 8개 센터의 다양한 기술 분야를 손쉽게 모니터링하고 지역 주민들의 피드백을 혁신 기술에 반영함으로써 신남방 지역내의 스마트한 기술혁신 프로그램을 구축할 수 있다.

\subsection{ICT 기반 글로벌 핵심기술 운영 플랫폼 및 성과 확산} 스마트 운영 시스템 구축을 통한 글로벌 핵심기술의 $\mathrm{R} \& \mathrm{BD}$ 협력사업 및 성과확산 추진과 글로벌 핵심기술 성 과확산을 위한 온·오프라인 기술운영 및 스마트 플랫폼을 구축하고자 한다. ICT 기술을 이용한 스마트 기술운영 플 랫폼을 구축하여 거점국 및 주변국에 분야별 핵심 기술이 전 사업을 추진함으로써 기술 소개 및 신규 사업화 추진을 위한 방안과 성과확산을 도모하고자 한다. 센터에서 개발 된 분야별 핵심기술들을 시범사업으로 추진하면서 지역사 회와 현지 정부 관계자들에게 스마트 기술 운영 방법을 제 공하고 핵심기술들을 이전할 수 있는 운영 플랫폼을 센터 에 구축하고자 한다. 시범사업을 통해 핵심기술들을 현지 정부의 분야별 추천 기술 목록에 등록된다면 현지정부사업 뿐만 아니라 국제기구들의 국제개발협력 사업에서도 기술 적용 우선순위가 높기 때문에 센터의 핵심기술로 채택될 가능성이 있어서 센터 사업의 성과확산이 가능하다. 개발 도상국 정부 관계자들에게 센터의 핵심기술들을 이전하고 기술역량을 강화하기 위한 온·오프라인 교육 프로그램을 구축하고자 한다.

글로벌 핵심기술 성과확산을 위한 현지 관계자의 기술 교 육은 ICT 기술을 도입한 글로벌 스마트 기술교육 플랫폼을 구축하여 운영가능하다. 또한, 개도국 현지에 기술을 이전 하고 현지 파트너기관의 기술인력을 양성하며, 기술창업지 원 프로그램을 운영한다. 이를 통해서 운영체계 현지화하 고 현지 파트너 기관이 사업을 내재화 할 수 있도록 역량 을 강화한다. 


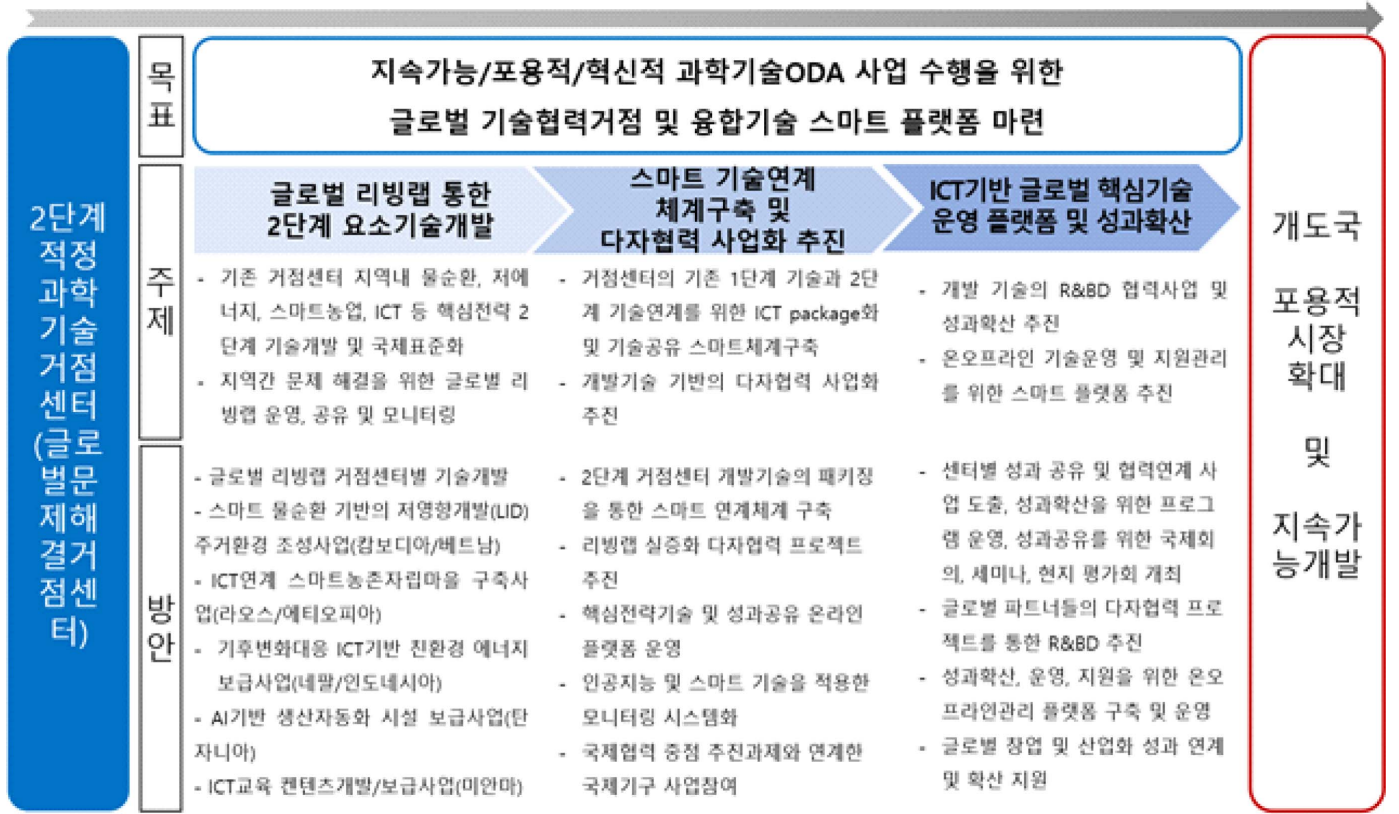

Figure 8. 2단계 거점센터 핵심 전략 로드맵 요약서

\section{2단계 거점센터 중점과제}

\section{1. 기존 거점센터 2 단계 전략기술의 ICT package 및 스마 트 시스템 구축}

순환/저에너지/스마트 농업/ICT 분야별 1단계 및 2단계 핵심전략 기술의 국제표준화 및 오픈소스화는 1 단계 거점 센터의 4 가지의 분야별 성과기술들을 2 단계 요소기술에 효 과적으로 적용시키 위해서는 현지 정부기관의 기술제도에 기반한 국제기술 표준화 작업이 요구된다. 또한, 센터의 요 소기술들을 오픈소스로 제공할 수 있는 스마트 기술정보 플랫폼을 구축하여 운영한다. 글로벌 리빙랩을 통한 분야 별 개발기술 및 ICT package 및 스마트 연계 시스템 구축 은 글로벌 리빙랩을 통하여 1 단계 센터에서 물/농업/에너 지/ITC에 대하여 개발된 핵심기술을 기반으로 2 단계 핵심 요소기술들을 기후변화 대응 물순환시스템/스마트농업/친 환경에너지/AI자동화기술 및 ICT 교육 등으로 향상된 기술 로 개발함. 또한 이를 공유할 수 있는 온·오프라인 ICT package 스마트 기술공유 플랫폼을 센터에 구축하여 운영 하고 한다. 개발기술에 인공지능 및 스마트 기술을 적용하 기 위한 운영, 관리 모니터링 요소 시스템 개발은 분야별 핵 심요소기술들을 인공지능 및 스마트 기술에 응용하여 개발 하고자 센터내의 스마트 운영관리 체계를 구축하고자 한 다. ICT 기술을 도입하기 위한 센터의 하드웨어 및 소프트 웨어를 구축하여 스마트한 핵심 요소기술을 개발하여 개발 도상국의 혁신기술로써 도약하고자 한다.

\section{2. 글로벌 리빙랩 중점기술에 대한 스마트 연계체계 개발}

물/저에너지/스마트 농업/ICT 분야별 지구촌 지역문제 해 결을 위한 기술뱅크 등 온·오프라인 혁신 플랫폼 개발은 거 점국 및 주변국에 적용 가능한 온·오프라인 분야별 핵심 적 용기술을 공유할 수 있는 스마트 기술정보 공유 혁신 플랫 폼이 요구된다. 센터별 핵심기술의 정보를 공유함으로써 지구촌의 다양한 지역문제를 해결할 수 있는 기술뱅크 등 의 역할을 통해서 추진될수 있다. 데이터 기반의 사회혁신 측정지수 개발 및 모니터링 성과평가는 ICT 기술을 이용한 스마트 기술정보 공유는 지역별, 국가별로 다양한 사용자 들에 의해서 누적된 데이터를 기반으로 분야별 사회혁신 측정지수를 개발하여 핵심기술의 우선순위를 결정할 수 있 다. 또한, 빅데이터를 분석함으로써 현지에 적용된 핵심기 술의 성과평가는 현지의 적절성, 효과성, 효율성, 지속가능 성을 모니터링하여 수행할 수 있다. 글로벌 리빙랩 기술공 유 스마트 연계체계 구축은 글로벌 리빙램 기술공유 플랫 폼은 온·오프라인 연계체계를 제공함으로써 신남방 지역의 주민들과 기술전문가들이 분야별 핵심기술들에 대해서 토 의하고 정보들이 공유할 수 있는 현실 및 가상공간을 제공 하여 운영할 수 있다.

\section{3. 거점센터의 기술성과 운영지원을 위한 글로벌 통합기술 (R\&BD) 비즈니스 지원 플랫폼 추진}

국제 창업경진대회, 학회, 포럼, 워크샵 등 성과확산 프로 그램 운영은 2 단계 거점센터의 핵심기술 개발에 대한 지속 
적인 홍보 및 기술이전은 국제 창업경진대회를 개최하여 대회 우승자에게 핵심기술이전과 교육 그리고 비즈니스 창 업을 위한 방안을 제시하고자 한다. 또한, 핵심기술의 성과 홍보를 위해서 학회, 포럼, 워크샵을 참석 및 개최하여 기 술개발 성과확산을 도모하고자 한다. 핵심전략기술의 글로 벌 비즈니스화 플랫폼 운영은 각 센터의 분야별 핵심기술 들을 주변국에 적용하고자 할 때 스마트 기술공유 정보 플 랫폼을 통해 현지 상황을 분석하고 모니터링함으로써 효과 적이고 성공적인 사업을 추진하도록 도움을 줄 수 있는 글 로벌 비즈니스 플랫폼을 운영하고자 한다. 글로벌 파트너 들의 다자협력 프로젝트 추진은 센터에 구축된 ITC 기반한 분야별 기술공유 스마트 플랫폼을 통해서 국내외 다양한 국제 협력 단체의 수요와 역량을 유기적으로 연계하여 글 로벌 혁신네트워크를 구축함으로써 글로벌 파트너들과의 다자협혁 프로젝트를 공동 기획하고 추진할 수 있는 방안 을 모색한다.

\section{결론}

우리나라의 연구개발집중도(R\&D intensity)는 국내총생 산(GDP) 대비 연구개발(R\&D) 지출이 $4.5 \%$ 로서 이스라엘 과 함께 세계 1 위에 해당한다(OECD, 2019). 이는 OECD 평 균인 $2.4 \%$ 의 2 배에 가까운 수치이다. 이러한 연구 역량을 통해서 우리나라 정부는 개발도상국 대상의 국제개발협력 사업으로 과학기술 $\mathrm{ODA}$ 의 개념을 정립하였으며 그간 다 양한 사업을 추진해 왔다. 현재는 과학기술 ODA의 대표적 인 사업이 과기부에서 지원하는 거점센터구축 사업이다. 최근 2 단계 거점센터 사업 추진을 위해 "신남방정책을 위 한 과학기술 ODA 추진 로드맵 도출” (Shin et al., 2020)이 라는 과학기술 $\mathrm{ODA}$ 전략 보고서를 과기부에 제출함으로 써 2단계 거점센터 사업의 방향성을 제시하였다. 2단계 거 점센터는 기존 8 개의 거점센터에서 성취한 다양한 분야별 성과들을 바탕으로 COVID19, 비대면사회, 디지털/그린뉴 딜, 기후변화, SDGs 달성 등의 신사업 분야 기술들을 R\&D 컨텐츠의 새로운 적용 분야들과 함께 글로벌 리빙랩 기반 의 STI 지원센터로 운영하고자 전략적 계획을 추진하고 있 다. 따라서 2단계 거점센터가 추구하는 전략적 추진과제로 는 3개의 핵심전략과제인 1) 거점센터 중심의 글로벌 리빙 랩 통한 2단계 요소기술개발, 2) 스마트 기술연계 체계구축 및 다자협력 사업화 추진, 3) ICT 기반 글로벌 핵심기술 운 영 플랫폼 및 성과확산과 3 개의 중점과제인 1) 기존거점센 터 2단계 전략기술의 ICT package 및 스마트 시스템 구축, 2) 글로벌 리빙랩 중점기술에 대한 스마트 연계체계 개발, 3 ) 거점센터의 기술성과 운영지원을 위한 글로벌 통합기술 (R\&BD) 비즈니스 지원 플랫폼 추진과 같은 사업들을 계획 하여 2단계 거점센터 사업을 구체적으로 제시하고 있다. 핵
심전략과제와 중점과제들을 통해서 우리나라의 과학기술 $\mathrm{ODA}$ 는 국제개발협력 사업을 통해서 개발도상국에게는 상 호간의 긴밀한 과학기술 협력관계로 구축할 수 있는 계기 될 수 있으며 선진국에게는 우리나라 과학기술 ODA를 역 량을 제시함으로써 과학기술 분야의 ODA 사업을 주도할 기회를 얻을 수 있다. 우리나라는 과학기술 전문성이 풍부 한 인력과 관련 조직적 운영체계가 이미 구축됨에 따라 충 분히 사업을 수행할 수 있는 잠재적인 능력을 보유하고 있 다. 또한, 과학기술 $\mathrm{ODA}$ 는 과기부뿐만 아니라 환경부, 국 토부, 외교부, 산자부, 특허청 등의 다양한 과학기술들을 보 유하고 이는 부처들과 협력하여 2단계 사업을 추진할 때 더 욱 큰 시너지와 함께 좋은 성과를 얻을 수 있을 것이다.

\section{사사}

본 연구는 한국연구재단의 2020년 정책용역연구과제 (20200411252-00)의 재원으로 수행한 연구과제 결과입니다.

\section{References}

Baek, W., Shin, J., Koo, K.-k., Jung, J., and Choi, S. (2020). A Study on Korean Public Diplomacy of Appropriate Technology, 6(2), pp. 103-114.

Choi, D. J. (2017). Report on Supporting the Sustainable Development of Appropriate Technology Center, National Research Foundation, pp. 153-165.

Lim, D. S. (2015). Analysis and Working Strategy of S\&T ODA, Journal of International Development Cooperation, 10(3), pp. 21-37.

Lee, D. Y. (2013). Past, Present and Future of Korean Appropriate Technology Strategy, Science and Technology Strategy, 23(4), pp. 118-129.

Lee, M. J., Jang, Y. S., Hong, S. B., Son, S. J., Lee, W. S., and Lee, C. K. (2014). Architecture of a global STI platform supporting 'creative economy' at global context, Strategy Research 201416, STEPI, pp. 79-92.

Ahn, B. I. (2015). The Status of Appropriate Technology: Analysis of Appropriate Technology Organizations and their Sustainability, Korean Report.

Lee, J. H., Dong, G. R. M., Yang, H. I., Sun, J. Y., and Maliphol, S. (2012). Innovative Strategy of S\&T ODA in Korea, Strategy Research, STEPI, pp. 1-346.

Lee, W. S., Hwang, J. T., and Kim, W. J. (2010). Collaborative Strategy of S\&T ODA in Cambodia, Vietnam and Phillipin for Sustainable development of ASEAN, Report 10-04-18, KIEP.

OECD, OCED Main Science and Technolgoy Indicator R\&D Highlights 2019, Directorate for Science, Technology and Innovation, March 2019. www.oecd.org/sti/msti2019.pdf.

Shin, K. W., Jeong, S. P., Park, H. K., and Park, E. S. (2020). S\&T ODA Roadmap for 2030 SDGs, National Research Foundation. 